\title{
Uma História da Lei Brasileira de Responsabilidade Fiscal
}

\section{A History of the Brazilian Fiscal Responsibility Law}

\section{JOSÉ ROBERTO R. AFONSO}

Economista e Contabilista, Professor de Mestrado do IDP, Pesquisador do IBRE/FGV, Doutor e Mestre em Economia, respectivamente, pela UNICAMP e pela UFRJ.

Data de Submissão: 11.02 .2016

Data da Decisão Editorial: 10.11 .2016

Data de Comunicação ao Autor: 10.11.2016

RESUMO: Este artigo procura resgatar motivações e história da elaboração do projeto de lei de responsabilidade fiscal e de sua apreciação pelo Congresso Nacional. Essa memória pode contribuir para compreensão de lei em que 0 Brasil foi pioneiro entre economias emergentes e optou por uma abordagem ampla, que mescla regras e medidas, e como em poucos outros países também alcança os governos estaduais e municipais. Na atual conjuntura, marcada por severa crise fiscal e longa recessão econômica, esse resgate histórico pode contribuir para avaliar a eficiência da citada lei e seu eventual reforço.

PALAVRAS-CHAVE: Finanças públicas; política fiscal; orçamento público; dívida pública; federalismo fiscal.

ABSTRACT: This article reviews the motivations and history of the elaboration of the bill of fiscal responsibility and its appreciation by the National Congress. This memory can contribute to an understanding of the law in which Brazil was a pioneer among emerging economies and opted for a broad approach that mixes rules and measures, and how few other countries also reach state and municipal governments. In the current situation, marked by severe fiscal crisis and long economic recession, this historical rescuecan contribute to evaluate the efficiency of said law and its possible reinforcement.

KEYWORDS: Public finance; fiscal policy; public budget; publicdebt; fiscal federalism.

\section{INTRODUÇ̃̃OO}

A crise fiscal que assola a economia brasileira, marcada por registro contínuo e até crescente de déficit primário no setor público, coincidindo 
com uma crise política, pode levar a resgatar dúvidas, polêmicas e questões que marcaram a apreciação e aprovação da chamada Lei de Responsabilidade Fiscal (LRF) - a Lei Complementar nº 101, de 04.05.2000'.

Uma lei de responsabilidade fiscal era um emblema de um governo e uma visão neoliberal da economia e das finanças públicas? A respectiva lei brasileira foi imposta pelo Fundo Monetário Internacional (FMI)? Ela visa tão somente a gerar superávit primário, crescente ou elevado, a qualquer pretexto?

Faltou sensibilidade social na elaboração de tal lei, que visaria a limitar e diminuir as intenções de gastos sociais tão necessárias? O gasto com juros não foi restringido pela lei? Os credores, bancários ou investidores, receberam tratamento privilegiado, inclusive para assegurar o recebimento do que os governos lhes deviam?

A visão fiscalista passaria a prevalecer sobre a visão política, e a tesouraria se imporia à vontade popular, quando aplicada a LRF?

A lei como um todo feria frontalmente a Constituição e ainda muitos de seus dispositivos contrariavam o interesse público? A independência dos Poderes Legislativo e Judiciário, bem como do Ministério Público e até mesmo dos Tribunais de Contas, princípio básico da democracia moderna, estaria sendo tolhida pelos limites para seus gastos com pessoal?

A LRF contrariaria a cláusula pétrea da Constituição da autonomia federativa? O rigor da lei seria aplicado apenas a prefeitos, quando muito a governadores, mas em nada alcançava o governo federal? A legislação fiscal e os controles contábeis e orçamentários constrangem, dificultam e impedem uma melhor atuação de um Presidente da República?

Se ninguém foi preso por conta da LRF posteriormente à sua aprovação, ela não pegou ou para nada serviria?

Esse amplo rol de questões, que até poderia ser ampliado com mais tempo e espaço, reproduzem críticas e acusações que já foram feitas ao correspondente projeto de lei e à própria LRF, cuja ementa é a seguinte: "Estabelece normas de finanças públicas voltadas para a responsabilidade na gestão fiscal e dá outras providências".

1 Como de praxe, as opiniões aqui expressas são pessoais e não das instituições a que está vinculado. 0 texto reproduz, parcialmente, informações e argumentos desenvolvidos pelo autor em Responsabilidade fiscal no Brasil: uma memória da lei, divulgado pelo IDP e FGV Projeto, em 2010. 
Além da lei complementar, outra lei federal, ordinária, foi proposta e apreciada junto com a LRF, a ela estando umbilicalmente vinculada e aprovada poucos meses depois, conhecida como Lei de Crimes Fiscais qual seja, a Lei no 10.028 , de 19.10.2000², com a seguinte ementa: "Altera o Decreto-Lei no 2.848, de 7 de dezembro de 1940 - Código Penal, a Lei no 1.079 , de 10 de abril de 1950, e o Decreto-Lei no 201, de 27 de fevereiro de 1967".

O objetivo deste artigo é recuperar a concepção, o desenho, a tramitação parlamentar e os questionamentos judiciais que marcaram a LRF ${ }^{3}$.

A proposta é resgatar a história da lei para contrapor as estórias que já a cercaram e que vez por outra são relembradas. Esta iniciativa já foi tomada por outros autores, inclusive objeto de livros já publicados, mas, pela relevância e complexidade desta lei, ainda há o que se acrescentar para compreensão de sua construção.

Ainda vale alertar que o artigo não tem por objetivo descrever e comentar o conteúdo da LRF - para tal finalidade, recomenda-se a obra de Oliveira (2013), entre dezenas de outros títulos, que detalha em pormenores a lógica e os impactos possíveis de cada um dos dispositivos da lei complementar.

\section{AS INICIATIVAS PARLAMENTARES}

A LRF regulamenta dispositivos constitucionais incluídos na Seção "Normas Gerais", do Capítulo "Das Finanças Públicas", do Título "Da Tributação e dos Orçamentos", da Constituição da República de outubro de 1988. Em particular, atende a previsão do art. 163, determinando que lei complementar disponha sobre finanças públicas. Vale transcrever o texto da Constituição vigente:

Art. 163. Lei complementar disporá sobre:

I - finanças públicas;

II - dívida pública externa e interna, incluída a das autarquias, fundações e demais entidades controladas pelo Poder Público;

III - concessão de garantias pelas entidades públicas;

2 Ver íntegra da lei em: <http://bit.ly/1MJ1KZz>.

3 Entre a rara literatura que detalha, passo a passo, a construção da LRF no Brasil, chama-se a atenção para a tese de doutorado de Cristiane Kerches da Silva Leite, "O processo de ordenamento fiscal no Brasil e na década de 1990 e a Lei de Responsabilidade Fiscal", defendida junto ao Departamento de Ciência Política da USP, São Paulo, em 2005. 
IV - emissão e resgate de títulos da dívida pública;

V - fiscalização financeira da administração pública direta e indireta; (Redação dada pela Emenda Constitucional no ${ }^{\circ}$, de 2003)

VI - operações de câmbio realizadas por órgãos e entidades da União, dos Estados, do Distrito Federal e dos Municípios;

$[\ldots]$.

A lei complementar sobre finanças públicas foi o primeiro dispositivo do capítulo constitucional com tal denominação - distinção nunca feita em nenhuma Constituição republicana -, no qual se inseriram as normas sobre orçamentos, incluindo as inovadoras leis do plano plurianual e das diretrizes orçamentárias anuais. Porém, pouca ou nenhuma atenção era dada às normas constitucionais que sinalizaram em favor da disciplina fiscal, como já alertara José Serra pouco depois de promulgada a nova Carta Magna ${ }^{4}$.

Estas disposições não constavam nas Constituições anteriores a 1988 e, por isso, o ponto de partida para resgatar sua memória é conhecer os trabalhos da Assembleia Nacional Constituinte ${ }^{5}$. As inovações sobre finanças públicas e orçamentos surgiram logo na segunda etapa de trabalhos - das chamadas comissões temáticas. Mais precisamente aparecem pela primeira vez no parecer apresentado em junho de 1987 pelo Relator Constituinte José Serra na comissão dedicada aos tributos, aos orçamentos e às finanças, presidida por Francisco Dornelles ${ }^{6}$.

4 Conforme José Serra (A Constituição e o gasto público. Revista Planejamento e Políticas Públicas, Ipea, p. 93-106, jun. 1989):

"As análises a respeito das consequências da Constituição de 1988 sobre as finanças públicas têm, em geral, enfatizado a prodigalidade fiscal e a ampliação da rigidez para reformar o setor público, implícitos no novo texto, bem como as características, méritos e limitações das mudanças no sistema tributário. Curiosamente, até agora, foram ignorados os dispositivos referentes à organização do gasto público, precisamente os mais positivos para os que se preocupam com as regras adequadas tanto ao equilíbrio fiscal como ao controle, à transparência e ao planejamento das decisões governamentais sobre a alocação de recursos."

5 Para mais detalhes sobre as definições de tais dispositivos na Constituição de 1988, ver o artigo do autor "Memória da Assembleia Constituinte de 1987/88: as finanças públicas", publicado na Revista BNDES, de junho de 1999 (Disponível em: <http://bit.ly/Zyyffp>).

Este resume publicado pelo mesmo autor, com Waldemar Giomi e José Carlos Polo, em "A legislação complementar sobre finanças públicas e orçamentos - subsídios e sugestões para sua elaboração" (Cadernos de Economia, Brasília: Ipea, n. 8, abr. 1992).

6 A memória dos trabalhos e anais da Assembleia Constituinte foi disponibilizada na Internet nos portais do Congresso Nacional. Sobre o tema ora em exame, é possível consultar a íntegra do primeiro documento apresentado a então Comissão da Tributação, Orçamento e Finanças, o substitutivo do Relator José Serra, em: <http://bit.ly/1MJ1Ro0>. O relatório final, aprovado pela mesma Comissão, está disponível em: <http:// bit.ly/1MJ1Z73>. 
Vale o trecho do relatório (página 13) em que apareceu pela primeira vez a referência ao comando que veio levar a criação da LRF, por iniciativa do Constituinte José Serra:

Seção II - Das Normas Gerais sobre Finanças Públicas

Art. 63. Lei complementar aprovará Código de Finanças Públicas, dispondo especialmente sobre:

I - finanças públicas;

II - dívida pública externa e interna, inclusive das autarquias, fundações e demais entidades controladas pelo poder público;

III - concessão de garantias pelas entidades públicas;

IV - emissão e resgate de títulos da dívida pública;

V - fiscalização financeira.

É curioso registrar, como se viu na citação anterior, que inicialmente foi utilizada a denominação Código de Finanças Públicas. Na justificativa de sua primeira proposta, o Relator Serra vinculou o código de finanças públicas à consolidação da legislação do sistema financeiro, a saber:

15. Importantes inovações do Substitutivo dizem respeito à Lei do Sistema Financeiro Nacional e ao Código das Finanças Públicas, que reestruturarão os sistemas financeiros público e privado, estabelecerão as novas regras pertinentes à organização e ao funcionamento desses sistemas. O eixo da reformulação e da consolidação desses corpos legais deverá ser a promoção do desenvolvimento equilibrado, com juros compatíveis com a produção; transparência das operações, sobretudo as que envolvam o setor público; controle social do gasto e da dívida pública; e inibição da especulação improdutiva como prática generalizada na vida econômica do País. (p. 15)

Pela tradição legislativa, a referência a código é feita quando se pretende reunir em um só ato as normas mais importantes referentes a uma matéria, buscando construir um fio condutor comum e critérios minimamente coordenados. Vale relembrar que o país já havia tido um código semelhante: o Decreto no 4.536, de 28.01.19227, organizou o Código de Contabilidade da União, com 108 artigos, que com o tempo acabou preterido pela prática de se elaborar uma lei básica para cada matéria - quando não várias leis, sem qualquer coordenação. 
A proposta do Relator José Serra foi mantida até o final dos trabalhos da Constituição, apenas sofrendo uma alteração de forma: nos trabalhos de revisão da redação, a referência ao código citado, pelo comando de que lei complementar disporá sobre finanças públicas (inciso I do caput do art. 163), além de outras matérias sobre dívidas públicas e sistema financeiro.

Promulgada a Constituição em outubro de 1988, a citada norma foi posteriormente ignorada por cerca de dez anos. Não tendo sido objeto de qualquer projeto de lei, nem por iniciativa do Executivo, nem de parlamentares.

O que muitos ignoram até hoje é que, na origem da LRF, está novamente o Congresso Nacional. O projeto de lei complementar do Executivo Federal para regulamentar a matéria não nasceu espontaneamente, mas, sim, decorreu de uma exigência parlamentar: foi exigida pela Reforma Administrativa - a Emenda Constitucional no 19, de 04.06.1998 -, que tramitou e foi promulgada meses antes de estourar a mais grave crise externa da década e o Brasil ter que recorrer ao FMI, tendo firmado acordo só em outubro daquele ano ${ }^{8}$.

A iniciativa parlamentar sobre a LRF, na verdade, é bem anterior a 1998 porque decorreu de sugestão apresentada para modificar a proposta de emenda datada de 1995 e introduzida logo no início de sua apreciação na Câmara dos Deputados. Vale reproduzir a norma, de caráter transitório, prevista naquela Emenda de 1998: "Art. 30. O projeto de lei complementar a que se refere o art. 163 da Constituição Federal será apresentado pelo Poder Executivo ao Congresso Nacional no prazo máximo de cento e oitenta dias da promulgação desta Emenda".

Portanto, ao contrário do que alegaram pouco depois os críticos do projeto da LRF, a sua proposição foi gestada por uma imposição - mas do Congresso Nacional. É uma criação genuinamente brasileira e não foi idealizada ou muito menos imposta pelo FMI ou qualquer organismo internacional.

8 O Programa com o FMI divulgado pelo Ministério da Fazenda, em 28.10.1998 (bem como o memorando do FMI, de 13.11.1998), distinguia entre medidas de ação imediata e outras de caráter estrutural, sendo a LRF incluída no segundo bloco - como um instrumento "capaz de instituir ordem definitiva nas contas públicas do conjunto dos Poderes e níveis de Governo". 


\section{PROPOSIÇÃO DO PODER EXECUTIVO}

Os princípios da Constituinte foram resgatados dez anos depois pelo Ministério do Planejamento, tendo à frente dos trabalhos Martus Tavares, inicialmente Secretário-Executivo e depois Ministro, que coordenou a elaboração pelo governo federal do projeto posteriormente enviado ao Congresso ${ }^{9}$, concebido como uma mudança de caráter estrutural e não mais uma medida imediatista, como era, por exemplo, a postergação da contribuição provisória sobre movimentação financeira (CPMF) ou o aumento da contribuição social sobre o faturamento (Cofins).

Havia um paradoxo intrínseco em sua formulação: o objetivo da LRF, no âmbito do chamado Programa de Estabilidade Fiscal (PEF) de 1998, era construir, a médio e longo prazos, um novo padrão de gestão fiscal que permitisse abandonar as práticas e políticas fiscais marcadas por visão e atuação mais urgente, que acompanhavam o programa; todavia, naturalmente, era-se obrigado a adotar na ocasião, diante da gravidade da crise econômica. Segundo técnicos do Executivo ${ }^{10}$, o projeto de LRF foi concebido para mudar o regime fiscal, abandonando-se a prática de recorrentes pacotes tributários de finais de ano, para patrocinar uma visão abrangente e intertemporal da realidade fiscal ${ }^{11}$.

9 Na preparação da proposição do Executivo Federal, o Ministério do Planejamento mobilizou o BNDES, que era vinculado a essa pasta na época, tendo o apoio técnico coordenado pelo autor deste trabalho e assistência jurídica contratada junto ao Dr. Cid Heráclito, ex-procurador da Fazenda. Depois, durante a tramitação do projeto no Congresso, o acompanhamento técnico do Ministério foi liderado pelo então Secretario-Executivo Guilherme Gomes Dias e pela assessora Selene Peres Nunes e, no campo política, pela então assessora parlamentar Selma Pantel.

Especificamente, o BNDES disponibilizou portal na Internet com uma biblioteca virtual chamada de Banco Federativo. Nela era possível encontrar centenas de documentos sobre finanças públicas e amplo acervo sobre a LRF, inclusive cada passo ou ato de sua elaboração, apreciação, votação e, depois, implantação. 0 BNDES editou, até 2002, cerca de duas dezenas de manuais e livros sobre a LRF, tendo sido distribuídos gratuitamente mais de 200 mil de seus exemplares (nenhum de autoria do BNDES, ou seus funcionários, e nenhum assinado pelo governo ou por uma de suas autoridades). Também foram organizadas teleconferências (inclusive com a ESAF) e cursos a distância de orientação não apenas para LRF (um deles promovido pelo IBAM e outro coordenado pela economista Sol Garson), como também ensinando pequenas prefeituras a melhor elaborar o PPA e a LDO. Uma pequena parcela do acervo da antiga biblioteca virtual foi resgatada e está disponível em: <http://bit.ly/1MJ3Kkw>.

10 Para uma análise das bases adotadas para elaboração do projeto de lei do Governo federal, vide Martus Tavares, Álvaro Manoel, José Roberto Afonso e Selene Peres, "Princípios e regras em finanças públicas: a proposta da lei de responsabilidade fiscal do Brasil", mimeo, apresentado no Seminário Regional de Política Fiscal da Cepal, Brasília, janeiro de 1999, e disponível em: <http://bit.ly/1MJ27n9>.

11 Segundo Tavares, Manoel, Afonso e Peres, no trabalho antes citado, p. 4:

"A Lei de Responsabilidade Fiscal - LRF insere-se nesse contexto porque, diferentemente das medidas de ajuste fiscal de curto prazo já implementadas, representa uma mudança estrutural do regime fiscal, introduzindo conceitos novos como os de responsabilidade e transparência e harmonizando diferentes normas para a organização e o equilíbrio das finanças públicas. Trata-se, portanto, de um verdadeiro código de boa conduta nas finanças públicas, aplicável aos três níveis de governo e aos três Poderes e em sintonia com os princípios constitucionais de autonomia federativa e de independência entre os poderes. Sua abrangência, 
Um aspecto peculiar da elaboração do projeto da LRF no âmbito do Executivo respeita à participação popular e às audiências realizadas para sua discussão e definição. Pela primeira vez, uma importante matéria fiscal foi submetida pelo Governo federal à consulta pública, em dezembro de 1998, antes do envio ao Congresso. Na data-limite prevista na emenda constitucional da reforma administrativa, o Poder Executivo Federal publicou, no início de dezembro de 1998, um anteprojeto de LRF ${ }^{12}$ no Diário

tanto em termos de matérias, como de conceituação de setor público e em termos temporais, é a maior possível."

12 É interessante apresentar a seguir a estrutura do anteprojeto do Executivo, mantida depois no projeto enviado ao Congresso, que é expressivamente diferente da que veio a ser editada no substitutivo aprovado pela Câmara dos Deputados e depois convertido na redação final da LRF:

"TÍTULO I - DISPOSIÇÕES PRELIMINARES

TÍTULO II - DA GESTÃO FISCAL RESPONSÁVEL DAS FINANÇAS PÚBLICAS

Capítulo I - Da Finalidade e Dos Princípios Fundamentais

Capítulo II - Das Normas Gerais

Seção I - Disposições Preliminares

Seção II - Da Limitação ao Endividamento Público

Subseção I - Das Restrições à Realização de Operações de Crédito

Subseção II - Da Vedação a Financiamento junto ao Banco Central

Subseção III - Dos Limites Globais para o Montante da Dívida

Seção III - Do Disciplinamento da Criação de Despesas

Subseção I - Da Criação de Despesas de Longo Prazo

Subseção II - Do Aumento dos Benefícios da Seguridade Social

Seção IV - Do Disciplinamento das Despesas com Pessoal

Subseção I - Do Aumento das Despesas

Subseção II - Do Custeio do Regime Próprio de Previdência Social dos Servidores Públicos

Subseção III - Dos Limites ao Montante das Despesas

Seção V - Da Prudência na Administração Financeira

Subseção I - Do Depósito das Disponibilidades de Caixa

Subseção II - Dos Limites às Inscrições em Restos a Pagar

Subseção III - Das Operações de Crédito por Antecipação de Receita

Capítulo III - Das Normas Próprias de cada Ente da Federação

Seção I - Dos Objetivos de Longo Prazo

Seção II - Das Metas Trienais

Capítulo IV - Da Correção de Desvios e Das Normas Coercitivas

Seção I - Das Operações de Crédito Irregulares

Seção II - Da Dívida Excedente aos Limites

Seção III - Da Criação de Despesa sem a Necessária Compensação

Seção IV - Da Despesa com Pessoal Excedente aos Limites

Seção V - Da Administração Financeira Imprudente

Seção VI - Do Não Cumprimento dos Objetivos e Metas Fiscais

TÍTULO III - DA TRANSPARÊNCIA FISCAL

Capítulo I - Da Abrangência das Contas

Capítulo II - Da Estruturação das Contas 
Oficial da União, acompanhado de extensa justificativa, e por meio dele abriu ao público em geral espaço para receber sugestões visando a sua revisão e elaboração do projeto a ser enviado ao Congresso Nacional poucos meses depois.

Por esse processo de debate público foram colhidas mais de $5 \mathrm{mil}$ sugestões pela Internet e realizadas várias audiências com diferentes representantes dos Governos estaduais e municipais e de entidades organizadas da sociedade. Dezenas de sugestões e pleitos assim recebidos foram incorporadas ao projeto final do Executivo. $\mathrm{O}$ caso mais marcante respeita à mudança na chamada Lei Camata, que seria incorporada à LRF e fixava os limites para despesas com pessoal, conforme comando constitucional. Os representantes dos governos estaduais, em particular, foram os que mais pediram para que se mudasse a lei então vigente e se inovasse ao fixar sublimites por Poder (aliás, os Governos mineiro e alagoano foram os principais defensores da proposta e, na época, seus governadores faziam oposição ao Governo federal). Esse processo amplo de debates também assegurou ao projeto, desde antes de seu envio ao Congresso, um amplo apoio dos formadores de opinião e da mídia.

Outra curiosidade histórica é que, em meio aos debates para elaboração do projeto de lei, técnicos do FMI chegaram a criticar o anteprojeto preparado pelo Executivo, por mesclar princípios com regras e compreender matérias muito diversas - mais especificamente, George Kopitz (responsável

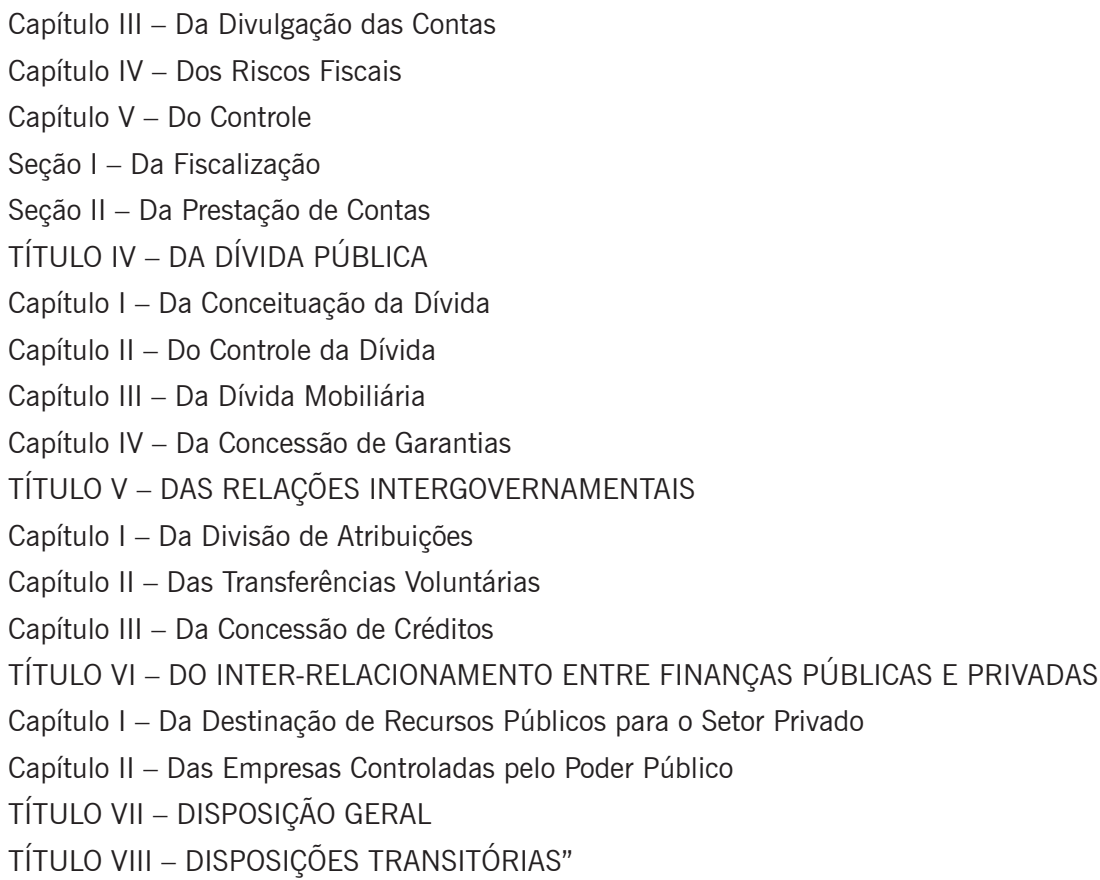


pela elaboração do Código de Boas Condutas Fiscais) manifestara muitas dúvidas e críticas ao anteprojeto em ofício de 19.02.199913.

Embora não fosse uma posição institucional do FMI, mas sim de um de seus técnicos, respeitado e especialista na matéria, a carta supracitada é inequívoca sobre as dúvidas e críticas que foram tecidas ao então anteprojeto brasileiro de LRF e, mais uma vez, contraria frontalmente a ideia então difundida à exaustão pela oposição, liderada pelo Partido dos Trabalhadores - PT, de que o projeto era imposição daquele organismo internacional.

Se a LRF fosse limitada ao ajuste fiscal, poderia ter se restringido a prever em seu próprio corpo a meta para resultados fiscais e de endividamento - a exemplo do padrão europeu do Tratado de Maastrich, em que a ênfase se dá ao percentual máximo de déficit aceitável, bem como ao limite de dívida (mas, na prática, quando superado, pelas nações mais poderosas do continente, as sanções foram suspensas). Se a lei tivesse seguido esse caminho, da opção por apenas limitar o déficit, pouco ou nada precisaria ter se importado em como prevenir e evitar que o déficit extrapolasse a meta; talvez, nem precisaria cuidar de como corrigir o resultado que ultrapasse a meta, porque, por princípio, o limite nunca poderia ser ultrapassado, mesmo em casos de anomalias econômicas (recessão) ou naturais (calamida-

13 Era a seguinte a argumentação básica de Kopitz do FMI (livre tradução):

"Ele é abrangente e ambicioso nos objetivos, cobertura institucional e características técnicas. Correndo o risco de omitir ou de interpretar mal alguns elementos-chave, estes comentários estão agrupados em três áreas: considerações estratégicas, desenho das regras fiscais e aspectos operacionais...

Considerações estratégicas - [...] Nesta conjuntura extremamente difícil do Brasil, para que as regras sejam críveis, elas devem ser adotadas como parte do programa de ajuste fiscal que assegure a convergência e, por conseqüência, o cumprimento das metas e limites estabelecidos no projeto de lei. Isso pressupõe uma estrutura tributária e um padrão de gastos que sejam duradouros, a um custo mínimo em termos de distorções e iniqüidades. Esse sistema fiscal, amplamente definido, deveria ser capaz de gerar superávits primários suficientemente grandes para facilitar a redução da dívida pública ao nível prudente prescrito na lei... Em suma, há fortes razões para perseguir a reforma das finanças públicas num amplo espectro - especialmente em tributação, previdência social, relações fiscais intergovernamentais - simultaneamente com a tramitação do projeto de lei de responsabilidade fiscal.

Desenho das regras fiscais - [...] Não está inteiramente claro no projeto de lei qual regra tem primazia sobre as outras. Num certo sentido, o conjunto prescrito de regras parece superidentificado. Alternativamente, elas podem ser inconsistentes. Notadamente, a contenção ou a redução da relação da dívida demandaria a geração de elevados superávits orçamentários primários - na medida em que a taxa de juros excede a taxa de crescimento do PIB por uma larga margem, como parece ser o caso do Brasil em um futuro previsível...

Aspectos operacionais - [...] Provavelmente serão encontradas consideráveis dificuldades na aplicação das penalidades anunciadas no projeto de lei - um aspecto-chave de credibilidade. À luz da recente suspensão do pagamento ao governo federal do serviço da dívida por alguns estados, pode ser necessário reforçar alguns dispositivos a respeito no projeto de lei... O projeto de lei coloca essa responsabilidade em última instância sobre o poder legislativo dos respectivos governos, o qual pode não estar isento de tendências políticas. O Tribunal ou o Conselho de Contas tem importante papel de supervisão no processo. Não está claro, contudo, se essa função é puramente de aconselhamento ou se inclui julgamento e arbitragem. Permanece a questão quanto a se essas entidades têm suficiente competência técnica e independência para exercer essas funções de modo objetivo. Outra questão surge quanto ao papel do Poder Judiciário na solução de disputas pendentes." 
des). Reduzir a LRF à mera fixação de um teto para déficit ou para dívida, no próprio corpo da lei, seria, a meu ver, a linha do menor esforço intelectual e legislativo, sem nenhuma garantia de eficácia. Basta lembrar que, pouco antes de o Brasil aprovar a LRF, a Argentina implantou lei semelhante, porém com arcabouço limitado apenas à fixação de um montante máximo de déficit público, que não permitiu seu controle e muito menos a falência do País.

Na época da preparação do projeto da LRF, como hoje, havia vasta literatura estrangeira, inclusive de dirigentes do FMI, mostrando que não havia uma solução ideal, muito menos simplista, nem para o ajuste fiscal imediato, nem para a sustentabilidade a médio e longo prazos no que tange ao controle da dívida ${ }^{14}$.

\section{APRECIAÇÃO PARLAMENTAR}

O projeto de lei complementar do Poder Executivo Federal (numerado como 18, de 1999) chegou à Câmara dos Deputados em 15.04.1999. Pouco depois (em 05.05.1999), foi constituída uma comissão especial para examinar a matéria, tendo na Presidência o Deputado Joaquim Francisco (PFL-PE) e na relatoria o Deputado Pedro Novais (PMDFB-MA).

14 Nunca é demais recuperar trechos de palestras de Tereza Ter Minassian, então diretora fiscal do FMI, que no X Seminário Regional de Política Fiscal da Cepal, em janeiro de 1998, alertou para o seguinte (livre tradução):

"[...] Assegurar uma firme redução da dívida pública requer uma combinação de ações voltadas para melhorar o equilíbrio fiscal primário e para reduzir, de maneira sustentada, o custo da dívida.

Crescentemente, os governos, especialmente nos países industrializados, têm se comprometido com políticas orçamentárias de horizonte de médio prazo, inclusive com trajetória de médio prazo para a dívida. Esse é o caso dos países da Comunidade Européia que aspiram à futura União Monetária. Na Nova Zelândia, a Lei de Responsabilidade Fiscal estipula uma trajetória de médio prazo para a relação entre dívida pública e PIB. Alguns países, como o Japão, não estabelecem limites explícitos para a dívida pública, mas aplicam a chamada 'regra de ouro', que proíbe a emissão de dívida pública para financiar déficits correntes do orçamento.

Nenhum limite sobre a dívida será eficaz para promover uma disciplina fiscal sustentada se não for:

a) abrangente, isto é, incluir todas as formas de dívida, seja externa ou doméstica, de curto ou de longo prazo, securitizada ou contratual (inclusive créditos de fornecedores), e também incluir as garantias públicas;

b) universal, isto é, aplicar-se aos governos central, estaduais e municipais, às agências descentralizadas do governo, e às empresas públicas, ao menos se garantidas pelo governo; e

c) monitorado periodicamente e de modo confiável.

A primeira experiência mais efetiva de controle do déficit público nos Estados Unidos ocorreu em 1985... A lei mostrou-se ineficaz, havendo o déficit efetivo ultrapassado as metas em todos os anos do período. 0 fracasso deveu-se ao fato de que o limite se aplicava sobre o déficit projetado e, assim, ações compensatórias para anular seus efeitos. Além disso, o controle baseado em projeções de déficit ensejou manipulações de estimativas orçamentárias e artifícios contábeis, que redundaram em déficits muito maiores do que aqueles que haviam sido orçados.

Como conclusão, uma boa administração da dívida pública é um complemento, não um substituto, de uma política fiscal responsável. A principal prescrição para um país sobrecarregado por uma grande dívida pública é manter importantes e sustentados superávits primários." 
Logo que o projeto da LRF chegou ao Congresso surgiu uma pequena confusão, de caráter mais técnico do que político e que ganhou pouca repercussão, alguns achavam que se tratava, ou preferiam, a regulamentação das normas gerais do orçamento - isto é, a revisão da Lei no 4.320, de 1964, recepcionada pela Constituição de $1988^{15}$. Porém, esse era o caso da lei complementar prevista no $\S 9$ o do art. 165 da mesma Carta Magna; porém, o próprio Congresso, na emenda da reforma administrativa, tinha cobrado do Executivo um projeto para regulamentar expressamente o art. 163, como já foi comentado; entretanto, o fez sem fazer referência à lei complementar citada na seção dos orçamentos.

O projeto de LRF teve boa receptividade no Congresso, a ponto de ser aprovado em apenas nove meses na Câmara. Depois de 27 reuniões da comissão especial, o parecer favorável, mas com alterações (na verdade, um substitutivo) do Relator Pedro Novais, foi proferido em 02.12.1999. A votação em Plenário começou em 20.01.2000 e a aprovação deu-se em 25.01.2000, com 385 votos a favor e 86 contra (entre eles os votos dos Deputados Antonio Palocci, Aloizio Mercadante e José Genoíno). Sobre o placar elevado, acrescente-se que apenas a emenda regulando a aplicação compulsória de recursos tributários no sistema único de saúde teve aprovação no Congresso Nacional por quórum superior à LRF no ano 2000.

O projeto (PLC 4/1999) chegou ao Senado em 03.02.2000, tendo sido relatado (a favor) pelos Senadores Álvaro Dias (PSDB-PR) na CC) (parecer aprovado em 24.02.2000) e Jefferson Peres (PDT-AM) na CAE (aprovado em 04.04.2000)16, depois de 3 audiências públicas. Em 11.04.2000, o mesmo projeto foi aprovado pelo Plenário do Senado por 60 votos contra 10. Mais

15 As diferenças entre as duas leis foi citada pelo autor no artigo de 1999, já citado:

"Não é demais chamar a atenção para o fato de que se tratam de duas leis complementares distintas, em princípio. No caso do art. 163, ou do projeto de lei de responsabilidade fiscal, o governo federal pretende torná-la uma espécie de código de boas condutas fiscais, que consolide e dê consistência às diversas normas gerais que tratam da captação de recursos (menos pela via tributária, sujeita a legislação específica), sua gestão e seu gasto, sempre respeitados os princípios constitucionais de autonomia federativa e independência de poderes. No caso do art. 165, será outra lei (para a qual já existe no Congresso mais de uma proposta de iniciativa dos próprios parlamentares) que tem por objetivo regulamentar os instrumentos e o processo orçamentário, bem como fixar normas específicas sobre a gestão financeira e patrimonial. Em princípio, a tramitação dos dois projetos deverá se dar de forma distinta, embora se espere que as decisões sejam harmônicas e coerentes."

16 O Relator Jefferson Peres era oposicionista ao Governo de Fernando Henrique. O Senador Jefferson Peres (Bloco/PDT-AM), figura respeitada no Senado pelas suas posições, assim justificou, de maneira contundente, porque encaminhou a favor da LRF:

"É por isso, Sr. Presidente, para que o Brasil deixe de ser um hospício financeiro, para que a gestão fiscal deixe de ser uma zorra, que tomei a decisão política, desde o início, de rejeitar todas as emendas, independentemente de serem meritórias ou não, a fim de que este projeto não retorne à Câmara, porque é preciso que ele entre em vigor imediatamente. [...] rejeito-as todas, com a consciência de que estou prestando um serviço ao País $[\ldots] "$ 
uma vez, a proposta de rejeição ao projeto foi comandada pelos senadores do PT (em particular, José Eduardo Dutra reclamava mais de inconstitucionalidade ao limitar operações de crédito e dívida, porque seriam matérias da competência exclusiva do Senado, e Eduardo Suplicy rejeitava a vedação para novas rolagens, temendo que prejudicasse as negociações em curso com a Prefeitura de São Paulo).

É importante chamar atenção para um ponto que muitos desconhecem: a Câmara dos Deputados, embora tenha preservado todos os princípios propostos pelo Executivo, promoveu expressivas mudanças na estruturação da lei e em sua técnica redacional, bem como incluiu importantes alterações que acentuaram ainda mais a austeridade fiscal do projeto, caso marcante das novas normas sobre a receita (inclusive para explicitar e dificultar suas renúncias) e sobre o Banco Central (separando as políticas fiscais e monetárias). Uma boa síntese das mudanças promovidas pela Câmara foi realizada por Fernando Silva ${ }^{17}$ :

Comparando-se o Substitutivo à Proposta original, o que se observa é que as grandes mudanças promovidas podem ser atribuídas: (a) à inclusão das receitas públicas como tema de relevante interesse para o fim de implantação do novo regime fiscal; (b) à enfática especificação dos novos papéis reservados às leis do plano plurianual, de diretrizes orçamentárias e orçamentária anual, tendo em vista a definição de estratégias, objetivos e metas de política fiscal; (c) à utilização da receita corrente líquida como elemento básico para o cálculo dos diversos limites aplicáveis às despesas e à dívida pública, em lugar da receita tributária disponível - originalmente proposta; (d) à manutenção das operações de refinanciamento da dívida mobiliária federal na lei orçamentária anual, em lugar de sua exclusão dos orçamentos públicos - conforme a proposta originalmente feita; (e) à definição de despesa obrigatória de duração continuada, em lugar da originalmente proposta despesa de longo prazo, para o fim de aplicação do mecanismo de compensação - "pay-as-you-go"; (f) à constituição do "conselho de gestão fiscal", integrado por representantes de todos os Poderes e esferas de governo, do Ministério Público e da sociedade civil, com o propósito de acompanhar e avaliar a política e a operacionalidade da gestão fiscal.

17 O consultor do Senado Fernando Veiga Barros e Silva, em nota técnica de 09.02.2000, assim comentou as alterações realizadas pela Câmara dos Deputados (p. 1 e 11):

"Na análise descritiva do Substitutivo, verifica-se que a finalidade primacial do Projeto de Lei Complementar encaminhado pelo Poder Executivo restou intocada. Trata-se da instituição de um regime fiscal-disciplinar, calcado em mecanismos de controle do endividamento e das despesas públicas, assim como em normas coercitivas e de correção de 'desvios fiscais' porventura verificados...

$[\ldots]$

De resto, as demais mudanças ou são pontuais ou podem ser imputadas à necessidade de reestruturação do texto original, adequando-o à técnica legislativa."

RDU, Porto Alegre, Edição Especial, 2016, 126-154, 2016 
Além de aperfeiçoar a forma e o conteúdo, o fato de a comissão especial da Câmara ter alterado muitos dispositivos do projeto do Executivo (com a concordância desse último) aumentou a adesão política dos parlamentares; mais uma vez, isso passou despercebido para aqueles que achavam que pouco depois o Congresso mudaria a lei.

Por último, vale comentar a questão federativa, que foi uma das mais destacadas pelos parlamentares que se opuseram ao projeto. Em termos partidários, houve uma contradição, algo sutil, entre as posições favoráveis ao projeto por parte de prefeitos e governadores vinculados à oposição (por exemplo, o governador de Alagoas apelou na Câmara para aprovação dos sublimites de gastos com pessoal), e as resistências e os votos negativos dos parlamentares dos mesmos partidos (que, no final, votaram em bloco a favor do Governo, nas duas Casas). Já, em termos de esferas de Governo, não houve uma ação coordenada dos governadores, ao contrário de prefeitos, especialmente os de cidades de pequeno porte que se reuniam em torno de confederação, que manifestaram desconforto, convertido em oposição ferrenha, depois de aprovada a LRF, quando se foi votar a lei de crimes fiscais ${ }^{18}$.

\section{O IMEDIATO PÓS-LEI}

A oposição ferrenha à LRF era exercida pelo Partido dos Trabalhadores $(\mathrm{PT})^{19}$.

18 Conclusões semelhantes foram manifestas por Cristina Leite em sua tese já citada (p. 159-161):

"Com relação à ação dos atores políticos federativos no processo decisório da LRF, a noção de Immergut sobre formação de pontos de veto no sistema político é bastante esclarecedora. 0 que observamos a partir da análise dos dados coletados? Os governadores e os prefeitos tiveram comportamento distinto no decorrer de todo o processo. Os governadores não agiram como atores com poder de veto no processo decisório da LRF. Eles agiram como facilitadores do processo, sugerindo ideias para o aperfeiçoamento da lei que convergiam com os seus interesses. Houve manifestações públicas de posições críticas, especialmente por parte de São Paulo, mas não houve uma mobilização política para pressionar as suas bancadas no Congresso, nem o Executivo Federal. Os entrevistados analisaram este fenômeno argumentando que os governadores ganhariam com a aprovação da lei, por duas razões básicas.

Primeiro, a possibilidade de financiamento por endividamento já havia sido encerrada com a renegociação das dívidas dos Estados, no âmbito da Lei no 9.496/1997...

Segundo, a LRF reduziria o ônus da realização do ajuste dos gastos com pessoal pelos Executivos Estaduais, especialmente ao estabelecer limites de gastos para os Poderes Legislativos e Judiciários estaduais...

A ação dos prefeitos foi diferente neste processo. Eles agiram de forma mais contundente, pressionando os deputados e senadores contra a aprovação da lei, através de marchas à Brasília, para fazer pressão sobre os parlamentares. Há algumas explicações para este comportamento diferenciado entre governadores e prefeitos. As condições de renegociação das dívidas dos Estados e dos Municípios foram diferentes. Os prefeitos tinham condições concretas de finanças públicas piores do que a dos governadores no momento da tramitação da LRF e agiram politicamente para defender seus interesses..."

19 Com relação ao termo "lei de responsabilidade fiscal", no sítio do PT (<www.pt.org.br>), uma pesquisa no link notícias, em 2000, revela as seguintes opiniões, entre outras: 
Durante o processo legislativo, não custa registrar que, pouco antes da votação na Câmara dos Deputados, o Relator Pedro Novais acatou várias emendas que contemplavam teses defendidas por deputados do $\mathrm{PT}^{20}-\mathrm{em}$ particular, visando a disciplinar o relacionamento do Fisco com o Banco Central, exigindo maior transparência e esclarecimentos sobre objetivos e impactos das políticas que executa, dispondo sobre o seu resultado periódico e, o principal, vedando a emissão própria de títulos da dívida ${ }^{21}$. A maior das contrições, entretanto, apareceria pouco depois de promulgada a lei, quando os mesmos partidos da então oposição (PC do B, PSB e, especialmente, o PT) pediram a inconstitucionalidade (ver detalhes adiante) de alguns dispositivos inseridos no corpo da LRF por emendas e teses defendidas por membros dos mesmos partidos, especialmente as que diziam respeito ao Banco Central.

Ainda assim, durante o encaminhamento da matéria, a liderança do PT encaminhou contra ${ }^{22}$, seus membros votaram contra e, mesmo depois

- do então líder do partido na Câmara dos Deputados, Aloizio Mercadante, explicando o motivo para votar contra o projeto:

"Primeiro porque ele é muito restritivo em relação aos gastos sociais e não coloca limites para gastos financeiros, para o pagamento de juros". O deputado diz que outro motivo para o PT votar contra é que a nova lei não permite a repactuação das dívidas. "Isso não existe no sistema financeiro", afirma. A terceira e última razão para votar contra a proposta do governo é sua lógica de submissão às regras do FMI. "A lei está totalmente concebida dentro da política de ajuste fiscal do FMI e abandona a perspectiva de solidariedade entre estados e União";

- do futuro líder do PT na Câmara, Professor Luizinho:

"Somos contra a LRF desde sua elaboração, pois sua única função é engessar o orçamento de Estados e Municípios para pagamento da dívida interna, em detrimento dos gastos sociais". Segundo o petista, não há qualquer artigo na lei que proteja as administrações municipais da corrupção. "A lei apenas evita que governos em final de mandato transfiram dívidas para as novas gestões".

- e do parlamentar do PT que mais acompanhou a matéria na comissão especial da LRF, Deputado João Fassarela:

"A LRF foi elaborada com o único objetivo de ajustar as contas dos municípios e Estados às diretrizes da dívida com o FMI", denuncia Fassarela. O deputado explica que, até então, o governo federal fazia acordos com Estados e Municípios para controlar o pagamento da dívida interna. "A partir da LRF, o governo federal passa a ter um instrumento de coerção e criminalização de prefeitos e governadores que não seguirem as diretrizes orçamentárias da União... Minha avaliação é de que a LRF funciona como uma intervenção direta do FMI nos municípios, pois transfere o superávit do orçamento para pagamento de juros de dívida em vez de financiar programas sociais".

20 Apesar de votarem no Plenário contra o projeto da LRF, junto com o PC do B e o PSB, o PT, paradoxalmente, apresentou muitas emendas a ele: 46 de autoria do líder João Fassarela e outras 4 de José Genoíno (PT-SP).

21 Na tese de Cristina Leite é registrado o que mudou de última hora (p. 127):

"Dentre as emendas integral e parcialmente aprovadas, destacaram-se três: a Emenda no 16 , que acrescenta ao art. 14 o $\S 4^{\circ}$, que veda a captação de recursos a título de antecipação ou pagamento de tributo cujo fato gerador não tenha ocorrido; a Emenda $n^{\circ} 65$, que muda a redação do art. 28 , deixando claro que não se proíbe o Banco Central de conceder às instituições financeiras operações de redesconto e empréstimos de prazo inferior a 360 dias; a Emenda $n^{\circ} 99$ (parcialmente aprovada), que altera 0 art. 64, mudando o limite de $\mathrm{n}^{\circ}$ de habitantes por Municípios de 20 mil para 200 mil que devem elaborar relatórios de prestação de contas..."

22 Tentando as manobras protelatórias habituais, o líder João Fassarela (PT-MG) apresentou requerimento para retirada do projeto da LRF da pauta da Câmara, que foi derrotado, mas usou a seguinte argumentação básica: 
de aprovada toda a lei, ainda apresentou alguns destaques que exigiram votações em separado de principais pontos do projeto, como, por exemplo, a vedação para novas renegociações da dívida entre os Governos (atacada em discurso pelo Deputado Aloizio Mercadante) ${ }^{23}$. A mesma situação se repetiu no Senado.

Poucas semanas depois de editada a LRF, em 29.06.2000, o Partido dos Trabalhadores (PT), junto com o Partido Comunista do Brasil (PC do B) e o Partido Socialista Brasileiro (PSB), protocolou no Supremo Tribunal Federal (STF), em 29.06.2000, uma ação direta de inconstitucionalidade, numerada como ADI 2.238 MC/DF, alegando dois motivos para que a Corte derrubasse integralmente a lei e, no caso disso não ser aceito, passando a questionar outros 25 pontos da $\mathrm{lei}^{24}$.

"Essa lei tem uma origem: é uma imposição do Fundo Monetário Internacional ao País. Sras. e Srs. Deputados, acho que ninguém aqui afirmará que o FMI está preocupado com a moralização das nossas Prefeituras. Não é essa a preocupação do FMI. Ao impor essa lei à Nação, inserindo-a no acordo e no ajuste, o FMI tem um único objetivo: que o Governo brasileiro diga aos credores internacionais que, independentemente do que acontecer no País, os interesses, os compromissos com os juros e com a dívida serão honrados. O FMI quer que o Congresso Nacional aprove hoje esse compromisso."

Curiosamente, quem respondeu ao Deputado João Fassarela foi o líder de um partido de oposição, o Deputado Miro Teixeira, líder do PDT:

"[...] Não percebo que se esteja atendendo qualquer exigência do FMI. Se o FMI dependesse de lei aprovada no Congresso Nacional para que suas exigências fossem, ao longo de décadas, atendidas pelos sucessivos Governos brasileiros, o País estaria bem melhor, porque nada teria sido atendido. Não é a lei que determinará se as metas e os compromissos com o FMI existirão ou não."

23 Cristina Leite assim chama comenta tal votação em sua tese (p. 131):

"Talvez a DVS (destaque para votação em separado) que trouxe a discussão do tema mais polêmico foi a $n^{\circ} 9$, sobre as operações de crédito entre entes federativos. O DVS de iniciativa da bancada do PT foi uma tentativa de alterar o art. 35, que veda as operações de crédito entre entes federativos, subtraindo do texto os casos de crédito por novação e refinanciamento, como a mesma bancada já havia tentado através de Emenda de plenário no ${ }^{\circ}$. 0 Deputado Waldir Pires (PT-BA) fez discurso contundente contra a proibição de empréstimos entre entes federativos, afirmando que a aprovação desse artigo era uma ameaça à federação, era inconstitucional e feria a autonomia dos Estados (DCD, 5750, 02.02.2000). [...] Segundo o Deputado Aloizio Mercadante (PT-SP), a lei acaba com a possibilidade de renegociação da dívida, o que é perigoso, porque não se sabe como vai ser a taxa de juros internacional. A Resolução no 78 já estabelecia a política e os parâmetros da renegociação. A lei privilegiava a visão da tecnocracia, que tem visão de tesoureiro, em detrimento da visão política, do Senado e do Congresso como instâncias de definição da política de negociação (DCD, 5752, 02.02.2000). A despeito dos argumentos dos deputados da bancada de oposição, um dos mais importantes artigos do projeto não foi alterado, em função da larga margem de votos: 304 favoráveis, pela manutenção da expressão, e 127 desfavoráveis..."

24 Na ocasião, a Liderança do PT na Câmara dos Deputados distribuiu a seguinte justificativa para a ação: "06.07.2000 - Oposição tenta anular na justiça Lei de Responsabilidade Fiscal

Os partidos de oposição PT, PC do B e PSB entraram na Justiça essa semana com ação direta de inconstitucionalidade (Adin) contra a Lei $n^{\circ} 101$ de maio deste ano, que estabelece normas de finanças públicas voltadas para a responsabilidade na gestão fiscal.

$\mathrm{Na}$ justificativa os partidos pedem a total nulidade da lei. 'Além de ferir os princípios federativos, 25 dos 75 dispositivos da lei são inconstitucionais', afirma a assessoria jurídica do PT.

As inconstitucionalidades são quase todas de invasão de competência de poderes. A lei concede prerrogativas ao Executivo que são do Congresso Nacional. A União pode, agora, fixar limites de gastos da dívida pública, atribuição da Câmara e do Senado. Segundo a assessoria do PT, com a lei, o Executivo invade também competências do Estado e dos Municípios." 
A inconstitucionalidade completa da LRF segundo os três partidos decorreria: primeiro, de vício do processo legislativo, pois o projeto teria sido emendado no Senado (e eles alegavam que eram emendas de redação) e não retornado para a Câmara; segundo, de um erro na abrangência parcial, pois foi feita uma "regulamentação parcial do que é indivisível, ou seja, dos incisos do art. 163 da CF" (p.14 da ADI), não tendo o STF aceitado tal argumentação.

A citada ação dos partidos da então oposição apenas abriu uma frente em que várias outras foram apresentadas junto ao STF visando a derrubar pontos específicos da LRF, mas a que ficou mais marcada na mídia acabou sendo aquela liderada pelo $\mathrm{PT}^{25}$.

A votação de tal ação, relatada pelo Ministro Ilmar Galvão, começou surpreendentemente poucos meses depois de apresentada, em 28.09.2000, embora o julgamento só tivesse sido formalmente concluído em 09.08.2007. Logo de início, o STF rejeitou a derrubada integral da LRF26.

A Corte passou à discussão pontual, e em vez de se seguir a numeração da lei ou dos dispositivos da ADI, passou direto ao dispositivo que criava sublimites de gastos com pessoal por Poder. A LRF acabou mantida por apenas um voto, sendo decisivo o do então Presidente daquela Corte, Ministro Marco Aurélio, que mudou o seu voto inicial (contrário) e acabou decidindo manter a constitucionalidade dos referidos sublimites de pessoal27. Aliás, pouco depois (09.05.2002), o mesmo ministro se posicionou de forma categórica a respeito da LRF em entrevista coletiva: "O Tribunal

25 Na tese de Cristina Leite, são relacionadas as várias ADIs contra a LRF (p. 146 a 149), valendo destacar as seguintes observações:

"As principais ADIns foram impetradas pelos partidos de oposição, pelos Tribunais de Contas e pelo Governador do Estado de Minas Gerais, Itamar Franco. A mais abrangente era a ADIn n²238, dos partidos de oposição. As demais questionavam basicamente os limites de gastos de pessoal por poder...

No caso da ADIn $n^{\circ} 2256$, a Atricon, na época em que a ADIn foi impetrada, era dirigida por técnicos do Estado de Minas Gerais. $\mathrm{O}$ advogado da associação era o filho do presidente do Supremo Tribunal Federal. Na época do julgamento, ao invés de ser julgada a ADIn impetrada pela Atricon, foi julgada a n 2238 , do PT, PC do B e PSB, que atingia mais pontos da lei. O Governo federal se mobilizou, tentando convencer os juízes de que os dispositivos, especialmente o do limite de pessoal, não era inconstitucional. O Governo acabou ganhando e o dispositivo foi mantido na lei."

26 Vale produzir a decisão do STF, disponível em seu portal, sobre a questão inicialmente levantada pela ADI 2238-MC/DF:

"O Tribunal, por unanimidade, rejeitou a argüição de inconstitucionalidade formal da lei, em sua totalidade, ao argumento de que o projeto deveria ter voltado à Câmara dos Deputados em razão de o Senado ter alterado certos dispositivos da lei. Votou o Presidente. Prosseguindo no julgamento, o Tribunal, por maioria, vencido o Senhor Ministro Marco Aurélio, rejeitou a argüição de inconstitucionalidade formal da lei, em sua totalidade, ao argumento de que o projeto teria que ter disciplinado por inteiro o art. 163 da Constituição Federal. Votou o Presidente. [...] Plenário, 28.09.2000."

27 A decisão do STF a respeito do dispositivo que fixava sublimites de gasto com pessoal por Poder é assim apresentada no seu portal, mais uma vez em relação à ADI apresentada pelo PT, PC do B e PSB: 


\title{
tem marchado com muita cautela com relação a essa lei, pois percebe que ela é um avanço em termos de Administração Pública"28.
}

\author{
Ao prosseguir na votação das dezenas de normas da LRF questiona- \\ das pela ação do $\mathrm{PT}^{29}$, PC do B e PSB, o STF aceitou e suspendeu apenas
}

“[...] Em seguida, após os votos dos Senhores Ministros IImar Galvão (Relator), Marco Aurélio, Sepúlveda Pertence, Octavio Gallotti e o Presidente (Ministro Carlos Velloso), deferindo a medida cautelar de suspensão dos efeitos do art. 20 da Lei Complementar $n^{\circ}$ 101, de 4 de maio de 2000, e dos votos dos Senhores Ministros Nelson Jobim, Celso de Mello, Sydney Sanches e Moreira Alves, que indeferiam a medida cautelar, o julgamento foi suspenso a fim de aguardar os votos dos Senhores Ministros Maurício Corrêa e Néri da Silveira, ausentes justificadamente. Plenário, 28.09.2000.

Decisão: Prosseguindo no julgamento, o Tribunal, por maioria, vencidos os Senhores Ministros IImar Galvão (Relator), Sepúlveda Pertence, Octavio Gallotti, Néri da Silveira e o Presidente (Ministro Carlos Velloso), indeferiu a medida cautelar de suspensão dos efeitos do art. 20 da Lei Complementar $n^{\circ} 101$, de 4 de maio de 2000. Retificou o voto proferido anteriormente o Senhor Ministro Marco Aurélio. Em seguida, o julgamento foi adiado por indicação do Relator. Plenário, 11.10.2000."

28 É interessante comentar que a referida entrevista foi dada em ocasião que o STF ameaçou voltar a examinar a questão da aplicação do sublimite de gastos com pessoal ao Judiciário. A maioria dos membros rejeitou manobra para reabrir o debate da matéria. O Ministro Marco Aurélio, na mesma entrevista, comentou a situação:

"Indagado sobre o porquê da proposta do Relator sobre o reexame do art. 20, ele respondeu que isso se deve à situação do estado de São Paulo, a qual chamou de 'dramática', onde os limites impostos pela LRF ao Poder Judiciário sobre as despesas de pessoal não é suficiente para que os órgãos da Justiça funcionem a contento, atendendo toda a demanda de processos.

Marco Aurélio, porém, disse que o melhor caminho seria a alteração da própria Lei Complementar $n^{0} 101 / 2000$, para que os limites de gastos determinados pela lei levem em conta o fator da densidade populacional. Ele afirmou que, segundo estimativas, um aumento entre $1 \%$ ou $1,5 \%$ seria o suficiente para que a Justiça pudesse arcar com o preenchimento de cargos vagos de magistrados e de servidores no estado.

O presidente do Supremo lembrou ainda que os três Poderes do estado de São Paulo gastam, juntos, menos com pessoal do que o previsto pela LRF e apenas o Judiciário sofre com as restrições. Por isso, ele concluiu que deveria ser possibilitado que um dos Poderes tenha seu limite aumentado, de modo a melhor atender 0 interesse da população, sem que isso implique gastos que extravasem o limite total definido pela lei."

Ver em: <http://bit.ly/1MJ2rSR>.

29 Justificativas para o PT questionar a LRF foram objeto de nota, em 13.10.2000, do seu Presidente, José Dirceu, da qual se pode destacar:

"A decisão do Supremo Tribunal Federal (STF), na última quarta-feira, dia 11, negando por seis votos a cinco, liminar para suspender o art. 20 da Lei Complementar no 101/2000 (Lei de Responsabilidade Fiscal), pedida pelo PC do B, PT e PSB através da ADIn 2.238, provocou equívoco grave quanto à intenção dos partidos signatários da ação. Com a iniciativa, os partidos levantam dúvidas em relação à constitucionalidade de alguns dispositivos da LRF.

Controlar gastos e sanear caixas estourados tornaram-se rotina para administradores do PT (prefeitos e governadores). Herdeiros de gestões financeiramente irresponsáveis, quase sempre de partidos que sustentam a aliança governista atual, nossos prefeitos e governadores despendem grandes esforços na busca do saneamento das finanças. A honestidade e a transparência administrativa, aliás, são ingredientes que levam o partido a conquistar sua mais significativa vitória eleitoral em seus vinte anos de existência.

[...]

É importante frisar que o motivo da referida ação direta de inconstitucionalidade não foi o de defender a irresponsabilidade fiscal. Na verdade, tornava-se necessário o pronunciamento imediato do Supremo Tribunal Federal acerca desse tema, porque havia sérias dúvidas quanto a adequada interpretação constitucional nessa matéria. A simples dúvida argüida pelos entes mencionados no art. 103 da Constituição Federal legitima 0 controle de constitucionalidade do STF. Aliás, a decisão liminar do Plenário da Suprema Corte, mantendo o texto integralmente, pelo resultado de $6 \times 5$, assim mesmo depois de um de seus ministros ter revertido o voto inicialmente dado, demonstra por si só o quanto a questão é controversa. 
três dispositivos. O primeiro envolvia uma brecha para que operações de crédito excedessem as despesas de capital no orçamento ( $\S 2^{\circ}$ do art. 12), suspenso porque a Constituição prevê a mesma coisa no art. 167, inciso III, mas de forma mais ampla, ao ressalvar despesas autorizadas mediante créditos suplementares especiais, mas não previstas na LRF. As outras disposições suspensas estão contidas no art. 23 da LRF e respeitam ao princípio constitucional da irredutibilidade de salários. Quando ultrapassado o limite de gasto com pessoal, o STF aceitou apenas a extinção de cargos e funções, mas não "a redução dos valores a eles atribuídos", não previsto pelo art. 169 da Constituição. Pela mesma razão, a íntegra do $\S 2^{\circ}$ do art. 23 da LRF foi suspensa, porque possibilita a redução temporária da jornada de trabalho com adequação de vencimentos ${ }^{30}$.

Voltando à promulgação da LRF, vale lembrar que apesar de ter sido aprovada pelo Congresso com quórum tão alto, suficiente para uma mudança constitucional, muitos ainda estavam descrentes de que o próprio projeto do Governo fosse aprovado pelo Congresso e, depois do sucesso, da implantação da lei ${ }^{31}$.

Duas curiosidades sobre a transição da LRF: primeiro, não se adotou uma sistemática geral de transição; segundo, a grande maioria das regras era de caráter autoaplicável e não dependia de regulamentação posterior.

O Partido dos Trabalhadores, ao lado de seus governadores, prefeitos e de sua bancada federal, é favorável ao limite de gastos com pessoal. Com sua iniciativa legal junto ao Supremo buscou, com celeridade, preservar a certeza e segurança jurídica, em conformidade com o direito constitucional e a harmonia entre os Poderes."

30 O STF aceitou questionamentos da ADIn 2.238-5 em relação aos seguintes dispositivos da LRF. Vale reproduzir os trechos correspondentes da decisão sobre tal ADI disponíveis no portal do STF:

"Decisão: [...] E, também por unanimidade, deferiu o pedido de medida cautelar para suspender a eficácia do $\S 3^{\circ}$ do art. $9^{\circ}$ da mesma lei complementar. Votou o Presidente. Em seguida, o julgamento foi adiado por indicação do Senhor Ministro-Relator. Plenário, 22.02.2001.

[...]

Decisão: [...] Por unanimidade, o Tribunal deferiu a medida acauteladora para suspender a eficácia do $\S 2^{\circ}$ do art. 12 , e no $\S 1^{\circ}$ do art. 23 , da expressão quanto pela redução dos valores a eles atribuídos, e, integralmente, a eficácia do $\S 2^{\circ}$ do referido artigo... Plenário, 09.05.2002.

$[\ldots]$

Decisão: Por unanimidade, o Tribunal conferiu interpretação conforme a Constituição Federal ao inciso II do art. 21, para que se entenda como limite legal o previsto em lei complementar, e, quanto ao art. 72 , para que se entenda como serviços de terceiros os serviços permanentes. Votou o Presidente. [...] Plenário, 12.02.2003.

[...]

Decisão: Fica retificada a decisão proclamada na assentada anterior para constar que, quanto ao art. 56, caput, da Lei Complementar no 101/2000, o Tribunal, à unanimidade, deferiu a cautelar, nos termos do voto do Relator. Ausente, nesta assentada, o Senhor Ministro Eros Grau. Presidência da Senhora Ministra Ellen Gracie. Plenário, 09.08.2007."

31 Menciona-se que no dia da promulgação da LRF, em 4 de maio, um único artigo foi publicado na grande imprensa nacional, saudando a nova legislação, assinado por José Serra e o autor deste trabalho, "Prática em vez de Promessa", no Jornal Valor Econômico (Disponível em: <http://bit.ly/1MJ2uxU>). 
Sobre a regulamentação da LRF, observa-se que foi reduzida a tão somente dois casos (limites da dívida e Conselho de Gestão Fiscal), nenhum deles dependendo da decisão exclusiva do Executivo. Por ser uma lei de caráter nacional, ou seja, aplicada a todas as esferas de Governo e todos os Poderes, vale ressaltar que os congressistas adotaram como princípio básico de trabalho deixar qualquer providência que interferisse nos rumos da LRF ao critério exclusivo do Governo federal.

No caso da dívida, como já determinava a Constituição de 1988, caberia ao Senado fixar limites para a dívida consolidada ${ }^{32}$ e, ao Congresso, limites específicos para a dívida mobiliária federal ${ }^{33}$ (aliás, como isso nunca foi feito, muitos esquecem que o comando é constitucional, e não da LRF). Pouco depois de promulgada a LRF, o Presidente da República enviou proposições ao Congresso para tratar desta matéria. Só foram aprovados novos limites e condições para dívidas estaduais e municipais, bem como para operações de crédito da União. Não foram fixados os dois limites para a dívida federal - por meio de resolução do Senado, para a dívida consolidada, e por meio de lei ordinária, específico para a dívida mobiliária ${ }^{34}$.

32 Em 03.08.2000, o Presidente da República encaminhou proposta (Mensagem n 154, de 2000) ao Senado Federal para fixar o limite para a dívida consolidada da União: no conceito líquida, em 3,5 vezes a receita corrente líquida, além de dispor de matérias correlatas. Atualmente, a proposta está sendo relatada pelo Senador José Serra, que apresentou parecer revendo expressivamente o texto original e, mesmo com oposição do governo federal, tenta aprovar naquela Casa. Ver tramitação legislativa e textos propostos disponíveis em: $<$ http://bit.ly/1MJ5f2i > .

33 O Poder Executivo federal enviou projeto em 03.08.2000 (Mensagem n 1.070), numerado como Projeto de Lei n 3.431, de 2000, na Câmara dos Deputados. Propunha que o montante da dívida mobiliária federal não ultrapasse a $650 \%$ da receita corrente líquida. Aparentemente o projeto foi arquivado.

34 O Presidente da República encaminhou ao Senado Federal a Mensagem n 154, de 03.08 .2000 ( $n^{\circ} 1.069$, de 2000, na origem), com duas propostas de limites globais para os montantes das dívidas consolidadas dos entes que constituem a República Federativa do Brasil: uma para a União e outra para os Estados, o Distrito Federal e os Municípios. Em 18.10.2000, a Presidência do Senado Casa determinou a autuação das duas propostas em processos autônomos, atribuindo-se a designação de Mensagem no 154 , de 2000, à proposta relativa à União, e de Mensagem no 154-A, de 2000, à referente aos Estados, ao Distrito Federal e aos Municípios, com o posterior encaminhamento de ambas ao exame da Comissão de Assuntos Econômicos (CAE). A Mensagem n 154-A, de 2000, aprovada em 20.12.2001, transformou-se na Resolução do Senado Federal $n^{\circ} 40$, de 2001, que dispõe sobre os limites globais para o montante da dívida pública consolidada e da dívida pública mobiliária dos Estados, do Distrito Federal e dos Municípios, em atendimento ao disposto no art. 52, VI e IX, da Constituição Federal. Em seguida, aprovou-se, por iniciativa da CAE, mas tendo como base a proposta enviada pelo Governo Federal, a Resolução $n^{\circ} 43$, de 2001, que dispõe sobre as operações de crédito interno e externo dos Estados, do Distrito Federal e dos Municípios, inclusive concessão de garantias, seus limites e condições de autorização, e dá outras providências. 
No caso do Conselho de Gestão Fiscal (CGF) ${ }^{35}$, a pedido do próprio Congresso ${ }^{36}$, o Presidente da República enviou projeto de lei ao Congresso poucos meses após a edição da lei ${ }^{37}$, mas até agora a matéria sequer passou de seu estágio mais inicial. A maior resistência inicial provinha do PT (e da assessoria técnica da Comissão de Orçamento), que defendia transformar o referido conselho em um órgão auxiliar do Congresso, o que, a juízo do então Governo federal, abriria precedente para propostas semelhantes relativamente a outros conselhos, como o Conselho Monetário. Recorda-se também que a própria LRF prevê que, na ausência do CGF, o Ministério da Fazenda disporia sobre elaboração dos relatórios exigidos pela lei. Tal regra de natureza transitória acabou desestimulando, indiretamente, a regulamentação daquele Conselho. As instruções baixadas pelo Ministério, por meio da $\mathrm{STN}^{38}$, em que pese o excelente caráter técnico, acabam não sendo obedecidas por todos os Governos do País - pior que isso, nem o próprio Tesouro segue suas instruções quando apura o superávit primário, ainda que seja uma das variáveis mais relevantes vistas pelos analistas fiscais ${ }^{39}$.

Pouco depois de promulgada a LRF, logo surgiu o reconhecimento pelas mudanças estruturais promovidas pela LRF, desde pesquisas de opinião pública ${ }^{40}$ até documentos oficiais de organismos internacionais. Para o

35 O Conselho de Gestão Fiscal já surge na LRF com definições de objetivos (desde a classificação e padronização das contas públicas até a transparência fiscal) e composição (representantes de todos os governos e todos os poderes), faltando ao projeto de regulamentação dispor sobre seu funcionamento. Por sua finalidade e ampla representatividade, o Conselho teria papel importante no suprimento de uma lacuna sobre aspectos operacionais da LRF, que hoje vem sendo coberta em grande parte por crescente atuação ex-ante dos Tribunais de Contas; porém, se isso não representa maiores riscos devido ao detalhamento e didatismo da lei, peca-se pela falta de padronização em nível nacional das práticas e interpretações.

36 A Lei de Diretrizes Orçamentárias da União para 2001, editada poucos meses depois de promulgada a LRF, previu que o Executivo Federal enviasse um projeto à Câmara dos Deputados, para regular a constituição e o funcionamento do Conselho, o que foi ainda no ano de 2000. Passados mais de doze anos de vigência da LRF, o referido projeto sequer foi examinado em primeira fase, por comissão temática daquela Casa. Em 2002, chegou a ser realizada uma mobilização política, inclusive com apoio dos dirigentes dos Tribunais de Contas pela aprovação da matéria. Porém, a partir de 2003, o Executivo tem se omitido sobre a matéria, nem incluído o projeto nas periódicas listas de projetos de lei prioritários.

37 Projeto de Lei $n^{\circ}$ 3.744, enviado pelo Poder Executivo Federal em 10.11.2000 (na origem, Mensagem no 1.658/2000). A mesa da Câmara dos Deputados despachou para apreciação inicial pela Comissão de Trabalho, Administração e Serviço Público e nunca foi votado, sequer debatido. Na última movimentação, em 26.03.2009, foi designado como Relator o Deputado Eudes Xavier (PT-CE).

38 Diversos manuais técnicos estão disponíveis no portal do Tesouro (como os relativos à elaboração de demonstrativos fiscais, de anexo de metas fiscais e resumido de execução orçamentária e de demonstrativo das aplicações obrigatórias da educação). Ver em: <http://bit.ly/1MJ2EW3>.

39 No caso do relatório resumido de execução orçamentário (RREO), o Manual da STN prevê que o Anexo VIII apresente um quadro com a apuração do superávit primário, detalhando e padronizando a forma como são divulgadas as receitas e despesas (pelo regime de competência) que levam àquele resultado. Enquanto a maioria dos grandes Governos estaduais e estaduais, a mesma STN divulga o mesmo quadro no RREO da União com outra formatação e seguindo um método completamente diferente. Ver os relatórios correspondentes do Tesouro em: <http://bit.ly/1MJ2Jcq >.

40 Por exemplo, pesquisa do IBEP, de meados de 2001, com parlamentares, formadores de opinião e jornalistas, a respeito da LRF, revelou que a grande maioria: 1 ) tem opinião favorável; 2) acredita que sua aprovação foi 
FMI, a LRF representou um "divisor de água", conforme avaliação extremamente positiva sobre as contas e práticas fiscais no País, sublinhando o grau de transparência fiscal alcançado, inclusive a liderança no uso do Governo eletrônico ${ }^{41}$. A OCDE também divulgou análise amplamente favorável à posição fiscal brasileira, com atenção aos avanços da LRF, ressaltando que os Governos subnacionais não mais ameaçam a estabilidade macroeconômica $^{42}$. Já o Banco Mundial destacou a revitalização do processo de planejamento governamental ${ }^{43}$. A Cepal, por sua vez, sempre abordou o tema em seminários focados em política fiscal, como o de novembro de 2001, que destacou a variedade de objetivos e temas tratados pela legislação brasileira $^{44}$.

mais para atender a uma pressão da sociedade por mudanças na administração pública do que devido a uma medida isolada do Governo Fernando Henrique; e 3) prevê como positivo um candidato à Presidente estar associado à lei.

41 Segundo o Report on the Observance of Standards and Codes (ROSC), IMF, November of 2001:

"In the last few years Brazil has achieved a high degree of fiscal transparency, together with major improvements in the management of its public finance...

The cornestone of these achievements has been the enactment in May 2000 of the Fiscal Responsibility Law which sets out for all levels of government fiscal rules designed to ensure medium-term fiscal sustainability, and strict transparency requirements to underpin the effectiveness and credibility of such rules of theses achievements has been the enactment in May 2000 of the Fiscal Responsibility Law...

Brazil has attained high standards with respect to main indicators of fiscal management and transparency. In particular, the following specific aspects are worth highlighting...

Brazil is at the forefront of countries at comparable level of development in the use of electronic means for the dissemination of fiscal statistics, legislation, and administrative regulation on tax and budgetary matters, and for delivery of government services, as well as to facilitate civil society's scrutiny of government activities and programs..." (p. 2)

42 Conforme citado na publicação "Brazil", OECD Economic Surveys, Paris: OECD, n. 15, jun. 2001:

"The government turned again to the issue of fiscal policy in order to redress fiscal imbalances and restore the credibility of fiscal policy... The new Fiscal Responsibility Law (FRL), approved in May 2000, was one of the instruments to ensure that the fiscal position of sub-national governments was consistent with this overall goal, through the law applies to all levels of government. The FRL is also improvising the transparency of public accounts and the budgetary process." (p. 69)

43 Assim foi registrado em estudo sobre o Plano Pluarianual - PPA (Planning for Performance in the Federal Government: Review of Pluariannual Planning, The World Bank, mimeo, September 2001):

"The new Law of Fiscal Responsibility is expected to rein in the hitherto irresponsible fiscal management by sub-national governments. But, for the time being, Brazil has no option but to continue to pursue tight fiscal policy and pursue structural reforms such as administrative reform and pension reform. Results of these measures are critical for the consolidation of the PPA." (p. 28)

44 Vide Carlos Oliva, "Fiscal Responsibility Laws: How Broad Should They Be", Seminário Cepal/BNDES, Rio, mimeo, nov. 2001. Também os especialistas Juan Carlos Lerda e Carlos Mussi, da Cepal, em "Novos instrumentos na política fiscal latino americana", mimeo, concluem:

"Uma lei de responsabilidade fiscal pode ser um pilar para o compromisso de um país em estabelecer um novo regime fiscal. A experiência internacional ainda é recente, mas demonstra que implementação não é uma tarefa fácil. No caso brasileiro, além dos méritos técnicos da Lei de Responsabilidade Fiscal, deve-se reconhecer o processo público de consulta realizado e o consenso político obtido na sua aprovação, que são elementos chaves para sustentabilidade de qualquer reforma estrutural. Como Oliva coloca no estudo, 'países tem que estar prontos' para explicitar a responsabilidade fiscal." 


\section{POLÊMICASE DEBATES}

É defendido que todas as vezes que a LRF foi submetida a um questionamento público saiu fortalecida do debate: seus princípios foram reafirmados, suas normas mais conhecidas e a fileira dos seus defensores ampliada.

No debate de caráter mais político, uma crítica de primeira hora apontava a centralização que a nova lei promoveria nas mãos do Governo federal. É importante ressaltar que a LRF não é um ato unilateral do Executivo Federal, não resultou e nem pode ser alterada, seja por decreto ou por medida provisória. Trata-se de uma lei complementar de caráter nacional e, como tal, aprovada por quórum qualificado do Congresso Nacional e aplicada às três esferas de Governo (central, estadual e municipal), e a cada um dos Poderes de cada governo.

Ressalte-se que a discriminação de regras por Poder, especialmente a fixação de limites para despesas com pessoal detalhados em sublimites, é consistente com a autonomia de cada Poder para dispor sobre contratação e remuneração de seu pessoal. Aliás, a natureza especial de uma lei complementar também é ignorada por muitos analistas, que, às vésperas da eleição presidencial, dizem-se preocupados com a continuidade da vigência da LRF no novo Governo, como se esse pudesse modificá-la por decisão unilateral.

Outra crítica recorrente, embora cada vez mais limitada a uma minoria de autoridades subnacionais, respeita à limitação da autonomia federativa imposta pela LRF. Por suposto, sua contrapartida deveria ser a transferência de poder decisório para as mãos do Governo federal; porém, os mesmos críticos são incapazes de especificar em que casos isso ocorreria. Não é demais lembrar que o Governo federal sequer tem o poder de fiscalizar e supervisionar o cumprimento dos limites e das exigências - atribuições constitucionais e, obviamente mantidas pela LRF, dos respectivos Tribunais de Contas.

A LRF atuou no sentido exatamente inverso: fortaleceu o federalismo e promoveu um salto em sua evolução, para um estágio de plena maturidade. Isso pode ser resumido na ideia de que cada Governo estadual e municipal passa a ser o único responsável por seus atos, cabendo apenas à população de sua jurisdição responder pelos seus eventuais acertos ou erros.

A lei inovou ao criar um conceito de Ente da Federação, que permitiu tratamento isonômico desde ao Governo federal até ao menor Estado e à menor prefeitura do País, todos submetidos às mesmas normas, limites e condições. Duas outras relevantes medidas para uma autêntica federação 
dizem respeito a: primeiro, atribuir à LDO de cada Estado e prefeitura a competência para fixar sua meta fiscal - aliás, nada impede que o resultado almejado seja um déficit, desde que o ente tenha capacidade de endividar-se e encontre quem o financie; segundo, vedar que um Governo financie ou refinancie outro governo, que um banco estatal empreste a seu controlador e que qualquer banco estatal financie despesas correntes.

Nunca é demais voltar à suposta contradição entre responsabilidade fiscal e social. Ela só existiria se fosse possível empreender gastos sociais com base em boas intenções, e não com recursos financeiros. Paradoxalmente, os que advogam uma lei nacional regulando a dita responsabilidade social são os que se intitulam arautos do federalismo e da autonomia subnacional, quando, na prática, se tal lei fosse exequível, teria de condicionar e tolher a forma de atuação dos Estados e Municípios, que centralizam quase todas as ações e gastos sociais do País (com a exceção da previdência social), ainda que, muitas vezes, com financiamento federal. E isso tudo, como se já não existisse uma série de vinculações de recursos públicos, inclusive inscritas na Constituição Federal e suas congêneres. Prever que a LDO de cada Governo especifique metas de ações sociais, se ao menos não violenta os preceitos federativos; por outro lado, não representa nenhuma novidade para os casos - como há anos já ocorre com a União -, em que as leis de diretrizes já especificam quais são os programas prioritários e, ao menos para estes, especificam o custo unitário de referência e as metas perseguidas.

É óbvio que nada é perfeito e sempre caberão aperfeiçoamentos e correções; porém, ainda parece cedo para chegar-se a tal ponto, uma vez que nem toda transição foi completada, inclusive porque ainda falta criar o único órgão regulamentador previsto na lei: o Conselho de Gestão Fiscal (CGF), a ser formado por representantes, não apenas das três esferas de Governo, como também de cada um de seus Poderes.

O mais curioso no caso do esquecimento do CGF é que este teria papel importante para ajudar no debate e nas definições, tanto para atualizar os padrões de classificações orçamentárias e contábeis - enquanto o Congresso não aprova uma lei complementar que revise a famosa Lei no 4.320 , de 1964 -, quanto para definir novos instrumentos, como o cálculo atuarial dos regimes próprios de previdência e o cálculo de riscos fiscais.

\section{OBSERVAÇÕES FINAIS}

A LRF é uma peça legal com poucos paralelos em outros países e, mais importante do que a lei, todavia, vem sendo a mudança de mentali- 
dade que viabilizou sua aprovação com amplo apoio da opinião pública e do Congresso.

Não resta dúvida de que a LRF representa mais do que uma simples lei tratando de finanças públicas (entre tantas outras leis brasileiras). Mudanças sociais significativas não ocorrem usualmente de forma abrupta nem como consequência de um único movimento ou ato. A cultura da gestão responsável dos recursos públicos no Brasil ainda está longe de ser uma conquista completa e acabada. O País já possui experiências concretas e bem-sucedidas, tanto de reequilíbrio das contas públicas quanto de modernização da gestão, inclusive com reconhecimento internacional, que devem ser disseminadas e fomentadas. Maior transparência fiscal, controle social e produtividade do gasto passarão pelo aproveitamento intensivo das novas e amplas oportunidades abertas pelas tecnologias de informação e comunicação.

Apesar dos enormes e inegáveis avanços já realizados, a LRF não pode ser vista como obra pronta e acabada ${ }^{45}$. Importantes instituições e limites até hoje não foram regulamentados.

A crise financeira global mudou o cenário fiscal no País: as despesas correntes em um patamar tão alto não mais poderão ser lastreadas pela receita que tende a diminuir, seja pelo efeito da recessão, seja pela concessão indiscriminada de incentivos. Acabaram os tempos de carga tributária abundante e crescente e o desafio macroeconômico está endereçado ao Governo federal.

À parte a premência em repensar a trajetória explosiva e de má qualidade do gasto público, o momento também é propício para retomar o processo de consolidação e modernização das instituições que assegure a sustentabilidade fiscal a longo prazo.

Um bom caminho é completar o que ficou inacabado na LRF e discutir o endurecimento das regras que tem sido insuficientes ou mesmo falhas. Vale repetir: o maior lapso envolve a dívida pública. A União responde por dois terços da dívida pública líquida (ou mais de $90 \%$ da bruta) e até hoje não está sujeita a qualquer limite, nem para sua dívida consolidada (competência exclusiva do Senado), muito menos para sua dívida mobiliária (lei ordinária). Nada justifica que o ente mais importante da Federação não es-

45 Este e os próximos parágrafos reproduzem opiniões manifestam pelo autor, em parceria com Marcos Nóbrega, no artigo chamado "Responsabilidade fiscal, muito por fazer", publicado no Jornal Valor Econômico, 7 maio 2009. Disponível em: <http://bit.ly/1MJ49U2>. 
teja sujeito a nenhum limite. Ademais, o presidente da República - a quem a Constituição delega a competência exclusiva para propor ao Senado a fixação ou a alteração do limite da dívida consolidada (art. 30, § 5º , da LRF) - deveria se manifestar anualmente sobre a manutenção ou a proposição de mudanças nos limites e nas condições aplicadas à dívida consolidada e nunca fez isso.

O Presidente da República também não tem assinado o Relatório de Gestão Fiscal (quadrimestral) no qual atesta que o Executivo Federal cumpre os limites previstos na LRF (como determina o seu art. 54, parágrafo único, III), embora o mesmo seja assinado pelos chefes do Supremo Tribunal Federal, do Senado Federal e da Câmara dos Deputados. Isso tudo não são apenas detalhes burocráticos. Tais omissões ferem claramente ditames legais e sinalizam descaso com outras esferas de Governo, com outros Poderes e com a própria sociedade.

Não há a menor lógica ou justificava para não se concretizar a instituição do Conselho de Gestão Fiscal (CGF). Embora a esfera federal seja pródiga e farta de conselhos, dispondo sobre os mais variados assuntos e com composições das mais abrangentes, até hoje não se aprovou (e sequer se discutiu) o projeto de lei, enviado ao Congresso poucos meses depois de editada a LRF, para definir a composição e o funcionamento do conselho fiscal.

O que a mídia tem noticiado há tempos respeita à maquiagem das despesas com pessoal, diante de certa leniência dos órgãos de controle e do próprio Governo federal que não reagem às distorções. Alguns Estados e Municípios não computam como gasto com pessoal a parcela da folha salarial correspondente ao IR retido na fonte dos respectivos servidores, que, por determinação constitucional, constitui receita própria da respectiva administração. Outros, excluem dessa despesa os gastos com inativos e pensionistas. Na essência, a ideia é que aposentadorias e pensões constituem um gasto com previdência (como de fato é) e tal é uma função de responsabilidade exclusiva do Poder Executivo; logo, não precisam ser computados na soma de despesas com pessoal dos outros Poderes. Quem assim interpreta não se preocupa em assegurar que o gasto esteja mesmo computado no outro Poder, o que provavelmente o levaria a extrapolar o seu subteto.

O pior ocorre quando o Executivo também exclui os gastos com seus servidores inativos e, aí, o montante da despesa com pessoal submetida ao controle da LRF se limita apenas a uma parcela do gasto: aquela dos servidores em atividade. Mais grave que tentar ludibriar a lei é não cumprir os 
ditames da Constituição que determinam (art. 169, § $3^{\circ}$ ) o corte de pelo menos $20 \%$ dos gastos com cargos comissionados e funções gratificadas, caso as despesas de pessoal estejam extrapoladas. Isso não tem ocorrido, por exemplo, no Ministério Público do Distrito Federal, que, extrapolando seus gastos com pessoal e apresentando grande quantidade de cargos comissionados, não sofreu nenhum corte de despesas por parte da União.

Já sobre o que mudar na LRF para torná-la ainda mais austera, vale chamar a atenção para as regras que ordenam a criação de gastos permanentes, inclusive a renúncia de receita. Falhou o princípio da compensação - só se cria gasto novo se houver corte de outro ou aumento de receita. Até se pode pensar em limites para despesas correntes, porém, continua sendo uma forma de controle ex-post, quando o mais importante e necessário é atuar ex-ante, de modo a restringir a criação de novos compromissos, inclusive exigindo a compensação financeira que comprove sua viabilidade técnica e orçamentária.

Isso remete a outra reforma crítica: deveria ser premente aprovar a lei complementar que regula os orçamentos, conquanto a atual (Lei no 4.320 , de 1964), recepcionada pela Constituição, resta anacrônica e incapaz de normatizar um processo orçamentário mais moderno, eficaz e transparente. Mas, aparentemente, não há maior interesse na aprovação dessa lei, nem mesmo no Executivo.

É preciso atentar que algumas autoridades e antigos críticos mais proferem fé na LRF do que a praticam no dia a dia. Não se devem confundir: instituições com medidas, aparato institucional para a formulação e execução de política fiscal com estratégia de atuação temporal, nem reforma estrutural com ajuste fiscal conjuntural.

Se a LRF virou quase unanimidade absoluta no cenário político e econômico nacional, o mesmo não se passou durante sua proposição e apreciação parlamentar e judicial, embora se antecipe que as fortes críticas vinham de uma parcela muito pequena de políticos ou partidos, e que foi derrotada por ampla margem no Congresso e na Suprema Corte.

Em essência, alegavam que a lei tinha sido imposta pelo FMI e tudo se prestava apenas à geração de superávit primário a qualquer custo. Refrescar a memória sobre a elaboração da lei é sempre um exercício interessante, inclusive para posterior avaliação dos resultados alcançados e para se pensar porque os críticos viraram possíveis defensores da LRF. 


\section{REFERÊNCIAS}

AFONSO, José Roberto. Memória da Assembleia Nacional Constituinte de 1987/88: As finanças públicas. Revista do BNDES, Rio de Janeiro: BNDES, n. 11, jun. 1999.

. Responsabilidade fiscal - A Agenda Incompleta. In: LEVY, E.; DRAGO, P. A. Gestão pública no Brasil contemporâneo. São Paulo: Edições Fundap, 2005. p. 185-197. tos, 2010.

Responsabilidade fiscal no Brasil: uma memória da lei. IDP e FGV Proje-

AFONSO, José R.; BARROSO, Rafael. Novos passos na construção do arcabouço institucional fiscal no Brasil: a premência da reforma da Lei no 4.320/1964. Revista de Controle e Administração, Município do Rio de Janeiro, v. II, n. 2, p. 153-170, jul./ dez. 2006.

AFONSO, José R.; NÓBREGA, Marcos. Responsabilidade fiscal, muito por fazer. Valor Econômico, 7 maio 2009.

- Responsabilidade fiscal: uma obra inacabada. Revista Controle do Tribunal de Contas do Estado do Ceará, v. VII, n. 1, p. 15-30, 2009.

AFONSO, José Roberto R.; GIOMI, Waldemar; POLO, José Carlos. Análise da atual sistemática de orçamento e planejamento e sugestões para o seu aperfeiçoamento. In: MATTOS FILHO, Ary Oswaldo (Coord.). Reforma fiscal: coletânea de estudos técnicos - Relatório da Comissão Executiva de Reforma Fiscal. São Paulo: Dórea Books and Art, v. II, 1993. p. 693-719.

GIAMBIAGI, F. Dezessete anos de política fiscal no Brasil: 1991-2007. Texto para Discussão do IPEA no 1309, 2007.

GIOMI, Waldemar. O orçamento público no Brasil. São Paulo, mimeo, nov. 1989. GREGGIANIN, Eugenio. Lei de responsabilidade fiscal - Aspectos críticos, mimeo, 2010.

LEITE, Cristiane Kerches Silva. O processo de ordenamento fiscal no Brasil e na década de 1990 e a Lei de Responsabilidade Fiscal. Tese. Departamento de Ciência Política, USP. São Paulo, 2005.

KHAIR, Amir; AFONSO, José Roberto; OLIVEIRA, Weder. Lei de Responsabilidade Fiscal: os avanços e aperfeiçoamentos necessários, 2006. In: MENDES, Marcos. Gasto público e ciente: propostas para o desenvolvimento do Brasil. São Paulo: Top Books e Instituto Braudel.

IMF. Report on the Observance of Standards and Codes (ROSC). Washington, DC: International Monetary Fund, nov. 2001.

NUNES, Selene. LRF - 8 anos: um balanço geral, Fortaleza, mimeo, 28 nov. 2008. 
OCDE. Brazil. Paris: Organisation for Economic Co-operation and Development, jun. 2001. OECD Economic Surveys, n. 15.

OLIVEIRA, Régis F. Curso de direito financeiro. São Paulo: Revista dos Tribunais, 2006.

OLIVEIRA, Weder. Curso de responsabilidade fiscal: orçamento, direito e finanças públicas. Forum, v. I, 2014.

PATURY, Luis Romero. Lei complementar sobre finanças públicas e sobre sistema financeiro. Cadernos de Economia, Brasília: Ipea, n. 7, abr. 1992.

SANTA HELENA, Eber. Competência parlamentar para geração e controle de despesas obrigatórias de caráter continuado e de gastos tributários. Temas de Interesse, Câmara dos Deputados, Brasília: Edições da Câmara, 2009.

SERRA, José. A Constituição e o gasto público. Planejamento e políticas públicas, Brasília/DF: Ipea, v. 1, n. 1, p. 93-106, jun. 1989.

TAVARES, Martus; MANOEL, Álvaro; AFONSO, José Roberto. Uma proposta para um novo regime fiscal no Brasil: o da responsabilidade fiscal. Anais do IX Seminário Regional de Política Fiscal, Brasília: Cepal/FMI/Bird/BID, p. C-205-230, jan. 1999.

TOLLINI, Helio M. Reforming the Budget Formulation Process in the Brazilian Congress. OECD Journal of Budgeting, v. 2009/1.

WORLD BANK (The). Planning for performance in the Federal Government. Review of Pluariannual Planning, Washington, DC, Sept. 2001. 